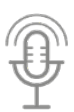

\title{
Risicofactoren voor een ernstig beloop van COVID-19
}

Wendy van den Oever, Vivian Raaijmakers, Anne-Mieke Theunissen, Mieke Wijnen-van Houts, Joost Frenken

\begin{abstract}
Dit is het eerste Nederlandse onderzoek naar risicofactoren voor een ernstig beloop van COVID-19. Hogere leeftijd en diabetes mellitus type 2 zijn geassocieerd met een hogere kans op ic-opname en overlijden. Deze patiëntengroep zou als eerste in aanmerking moeten komen voor vaccinatie, zodra die beschikbaar is.
\end{abstract}

Op 8 maart 2020 werd op de afdeling Spoedeisende Hulp (SEH) van het Elkerliek Ziekenhuis in Helmond de eerste patiënt positief getest op het virus SARS-CoV-2. Nadien werd duidelijk dat dit Noord-Brabantse ziekenhuis zich middenin een brandhaard bevond waar dit virus in de daaropvolgende maanden veel slachtoffers zou eisen. ${ }^{1}$ Onderzoeken wereldwijd, waaronder in China en in omliggende Nederlandse ziekenhuizen, beschrijven COVID-19 als een zeer ernstig ziektebeeld met een hoge mortaliteit (20-22\%) en veel ic-opnames (15-19\%). Veruit de meeste verwezen patiënten presenteren zich op de SEH met koorts (78-84\%) en luchtwegklachten (56-78\%). Atypische klachten als buikpijn, diarree en pijn op de borst worden bij ruim $35 \%$ van de patiënten gezien. ${ }^{2,3}$ De data geven echter nog onvoldoende antwoord op de vraag welke patiëntkenmerken bijdragen aan een ernstiger ziektebeloop bij Nederlandse patiënten. Factoren die daarbij vermoedelijk een rol spelen, zijn BMI, leeftijd en comorbiditeit. ${ }^{2-5}$

In dit onderzoek beschrijven we de kenmerken van de eerste 243 COVID-19-patiënten die in maart 2020 werden gezien op de SEH van het Elkerliek Ziekenhuis. Ons doel was te onderzoeken welke patiëntkenmerken zijn geassocieerd met een slechtere ziekte-uitkomst (ic-opname en/of overlijden). Daarnaast onderzochten we of vitale parameters en laboratoriumuitslagen voorspellende waarde hebben.

\section{METHODE}

Op de SEH werden patiënten met klachten van algehele malaise, koorts, respiratoire klachten, braken en/of diarree beschouwd als mogelijk besmet met SARS-CoV-2. We includeerden 243 patiënten die in de periode van 8 tot en met 31 maart 2020 de SEH bezochten en bij wie SARSCoV-2 werd aangetoond met een real-time PCR-test via een naso-orofaryngeale uitstrijk. De primaire uitkomstmaat was de ernst van het ziektebeloop, gedefinieerd als een ic-opname en/of overlijden binnen 1 maand na inclusie.

De gegevens zijn retrospectief verzameld vanuit de elektronische patiëntendossiers, waaruit ook geslacht, leeftijd, BMI, comorbiditeit en behandelbeperkingen werden overgenomen. Wanneer gewicht of lengte bij opname niet bekend waren, berekenden we de BMI met de meest recente bekende gegevens (tot maximaal 1 jaar oud). Aan comorbiditeit onderscheidden we de volgende categorieën: chronische longziekten (astma, COPD, longcarcinoom); cardiovasculaire ziekten (myocardinfarct, CVA); hypertensie; diabetes mellitus; immuundeficiëntie (bij gebruik van immunosuppressiva); maligniteit. We analyseerden het klachtenpatroon bij binnenkomst op de SEH (T0) aan de hand van de volgende symptomen: hoesten, koorts, moeheid/algehele malaise, dyspneu, hoofdpijn, braken, diarree, mictieklachten en pijn op de borst. Daarnaast verzamelden we de eerst genoteerde vitale parameters: ademhalingsfrequentie, zuurstofsaturatie (pulsoximeter, eventuele zuurstofsuppletie), hartfrequentie, bloeddruk en temperatuur (oorthermometer). Van de laboratoriumuitslagen noteerden we CRP, leukocytengetal, lymfocytenpercentage, trombocytengetal, LDH, ASAT, ALAT en bloedgroep, en ook de arteriële bloedgasanalyse indien aanwezig $\left(\mathrm{pH}, \mathrm{pCO}_{2}, \mathrm{pO}_{2}\right.$, bicarbonaat en lactaat).

Bij alle patiënten werd op T0 een X-thorax gemaakt en beoordeeld door de dienstdoend radioloog, met als mogelijk resultaat 'geen afwijkingen', 'unilaterale infiltratieve afwijkingen' of 'bilaterale infiltratieve afwijkingen'.

\section{Statistische analyse}

De gegevens zijn geanalyseerd met SPSS 23.0. Normaliteit 
toetsten we met de kolmogorov-smirnovtest in combinatie met een histogram. De kenmerken van de patiënten op T0 zijn geanalyseerd met een onafhankelijke t-toets voor normaal verdeelde continue variabelen, met de mann-whitney-u-toets voor niet normaal verdeelde continue variabelen en met de chikwadraattoets voor categorische en dichotome variabelen. Normaal verdeelde variabelen zijn beschreven als gemiddelden met standaarddeviaties, niet normaal verdeelde continue variabelen als mediaan met interkwartielafstand (IQR) en categorische variabelen als frequenties.

Met een binominale logistische regressieanalyse hebben we patiëntkenmerken geïdentificeerd die geassocieerd zijn met een ernstig beloop (ic-opname en/of overlijden). Parameters die in de univariabele analyse significant bleken $(\mathrm{p} \leq 0,05)$, zijn meegenomen in de multivariabele logistische regressieanalyse.

\section{RESULTATEN}

Tussen 8 en 31 maart 2020 presenteerden zich 865 patiënten op de SEH van het Elkerliek Ziekenhuis, van wie er 248 positief testten op SARS-CoV-2. We excludeerden 5 patiënten (1 opgenomen op de afdeling Kindergeneeskunde, 3 pas later op de afdeling getest en 1 poliklinisch getest) en konden dus 243 COVID-19-patiënten includeren.

\section{WAT IS BEKEND?}

- COVID-19 is een ernstig ziektebeeld met een hoge mortaliteit en veel ic-opnames.

- COVID-19-patiënten presenteren zich met een breed scala aan symptomen, meestal koorts en luchtwegklachten.

- Buitenlandse gegevens suggereren dat BMI, leeftijd en comorbiditeit voorspellers zijn voor een slechter ziektebeloop.

\section{WAT IS NIEUW?}

- Leeftijd en diabetes mellitus type 2 zijn geassocieerd met een hogere kans op ic-opname en/of overlijden.

\section{Onderzoekspopulatie}

Van de 243 geïncludeerde patiënten werden er $206(84,8 \%)$ opgenomen in het ziekenhuis. Voor 158 patiënten (76,7\%), die nog naar de ic zouden willen mocht het nodig zijn of bij wie dit medisch zinvol zou zijn, gold het ic+-beleid. Van hen werden er $40(25,3 \%)$ daadwerkelijk opgenomen op de ic voor respiratoire en/of hemodynamische ondersteuning. In

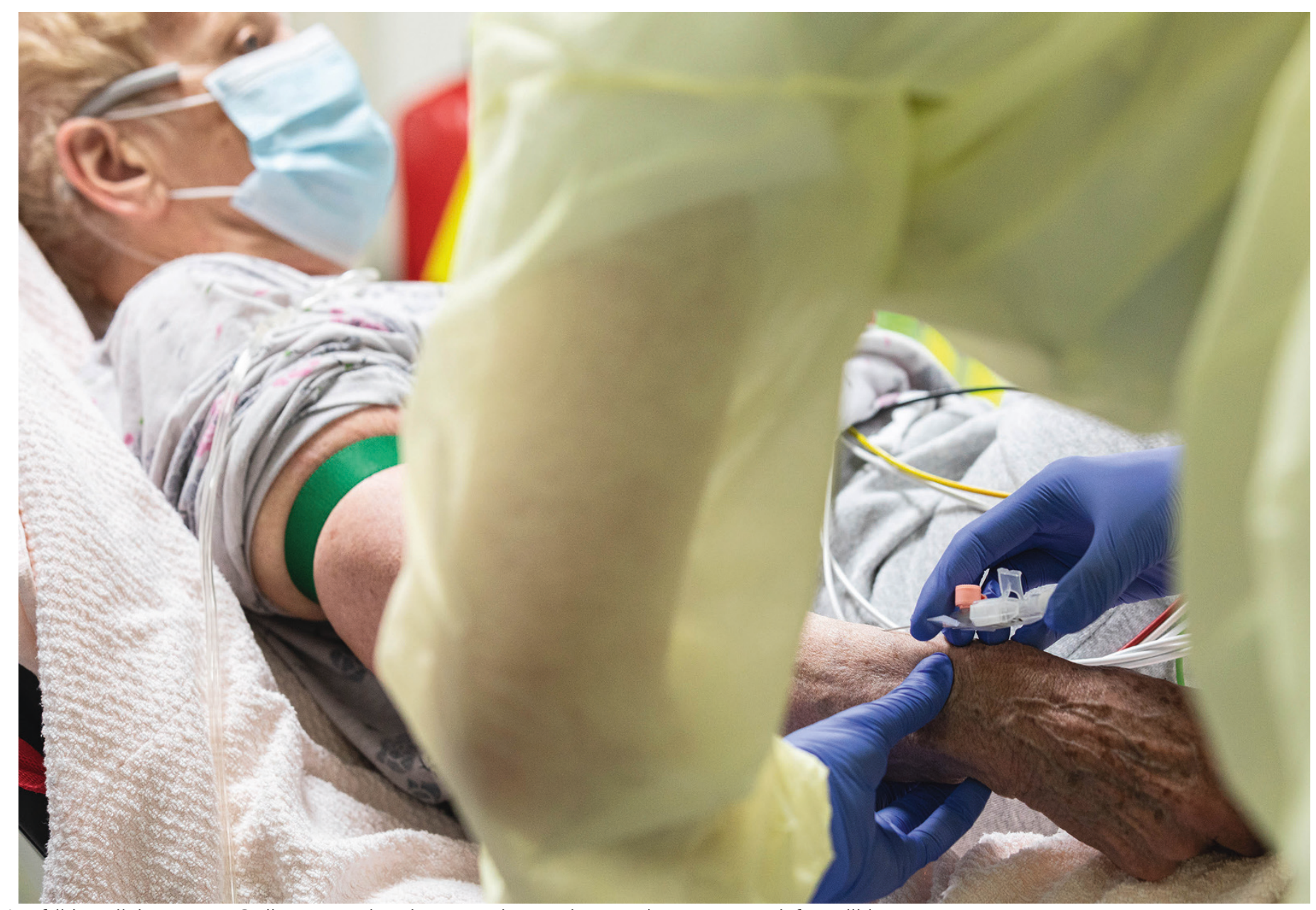


Aanvullende klinische kenmerken uitgezet tegen wel of niet overlijden

\begin{tabular}{|c|c|c|c|c|}
\hline Kenmerk & Totaal $[n=243]$ & Niet overleden [ $n=173$ ] & Overleden $[n=70]$ & $\mathrm{p}^{*}$ \\
\hline $\begin{array}{l}\text { Symptomen } \\
\text { hoesten [ } n=242] \\
\text { dyspneu [ } n=242] \\
\text { koorts } \\
\text { pijn op de borst } \\
\text { braken } \\
\text { moeheid/algehele zwakte } \\
\text { hoofdpijn } \\
\text { mictieklachten } \\
\text { diarree }\end{array}$ & $\begin{array}{l}n=241 \\
184[76,0 \%] \\
170[70,2 \%] \\
181[75,1 \%] \\
36[14,9 \%] \\
35[14,5 \%] \\
208[86,3 \%] \\
23[9,5 \%] \\
16[6,6 \%] \\
73[30,3 \%]\end{array}$ & $\begin{array}{l}n=172 \\
131[75,7 \%] \\
113[65,7 \%] \\
130[75,1 \%] \\
29[16,9 \%] \\
27[15,7 \%] \\
151[87,8 \%] \\
22[12,8 \%] \\
12[7,0 \%] \\
47[27,3 \%]\end{array}$ & $\begin{array}{l}\mathrm{n}=69 \\
53[76,8 \%] \\
57[81,4 \%] \\
51[75,0 \%] \\
7[10,1 \%] \\
8[11,6 \%] \\
57[82,6 \%] \\
1[1,4 \%] \\
4[5,8 \%] \\
26[37,7 \%]\end{array}$ & 0,015 \\
\hline $\begin{array}{l}\text { Controles } \\
\text { temperatuur, }{ }^{\circ} \mathrm{C} \\
\text { ademhaling, per minuut } \\
\text { zuurstofsaturatie, \% } \\
\text { systolische bloeddruk, mmHg }\end{array}$ & $\begin{array}{l}\mathrm{n}=242 \\
37,6[S \mathrm{SD} 1,0] \\
24 \text { [IQR 20-28] } \\
95 \text { [IQR 93-97] } \\
133[\text { [SD 21,5] }\end{array}$ & $\begin{array}{l}n=172 \\
37,6[\text { SD 1,0] } \\
24[\text { IQR 20-28] } \\
95[\text { IQR 90-96] } \\
133[\operatorname{SD~10,2]~}\end{array}$ & $\begin{array}{l}\mathrm{n}=70 \\
37,8[\mathrm{SD} 1,0] \\
24[\text { IQR 22-30] } \\
94[\text { IQR 90-96] } \\
134[\text { [SD 24,5] }\end{array}$ & $\begin{array}{l}0,025 \\
0,003\end{array}$ \\
\hline
\end{tabular}

Cijfers zijn aantallen, tenzij anders aangegeven. Normaal verdeelde continue variabelen worden beschreven als gemiddelde met standaarddeviatie [SD], niet normaal verdeelde continue variabelen als mediaan met interkwartielafstand [IQR], dichotome variabelen als frequentie.

* Significante associatie tussen uitkomst [wel of niet overlijden] en kenmerk $[p<0,05]$.

totaal overleden 70 patiënten $(28,8 \%)$ aan de gevolgen van COVID-19.

De mediane leeftijd van onze populatie was 72 jaar (IQR 60-78), de mediane BMI was 28,4 kg/m² (IQR 25,6-31,4), er waren 148 mannen $(60,9 \%)$ en 195 patiënten $(80,2 \%)$ hadden een comorbiditeit [online tabel 1]. Veruit de meeste COVID-19-patiënten presenteerden zich op de SEH met moeheid of algehele zwakte $(86,3 \%)$, hoesten $(76,0 \%)$, koorts $(75,1 \%)$ en dyspneu (70,2\%). Bij controle op T0 was de gemiddelde temperatuur $37,6^{\circ} \mathrm{C}(\mathrm{SD} 1,0)$, de mediane ademhalingsfrequentie 24/min (IQR 20-28), de gemiddelde zuurstofsaturatie

\section{Figuur}

BMI uitgezet tegen wel of niet overlijden bij COVID-19-patiënten

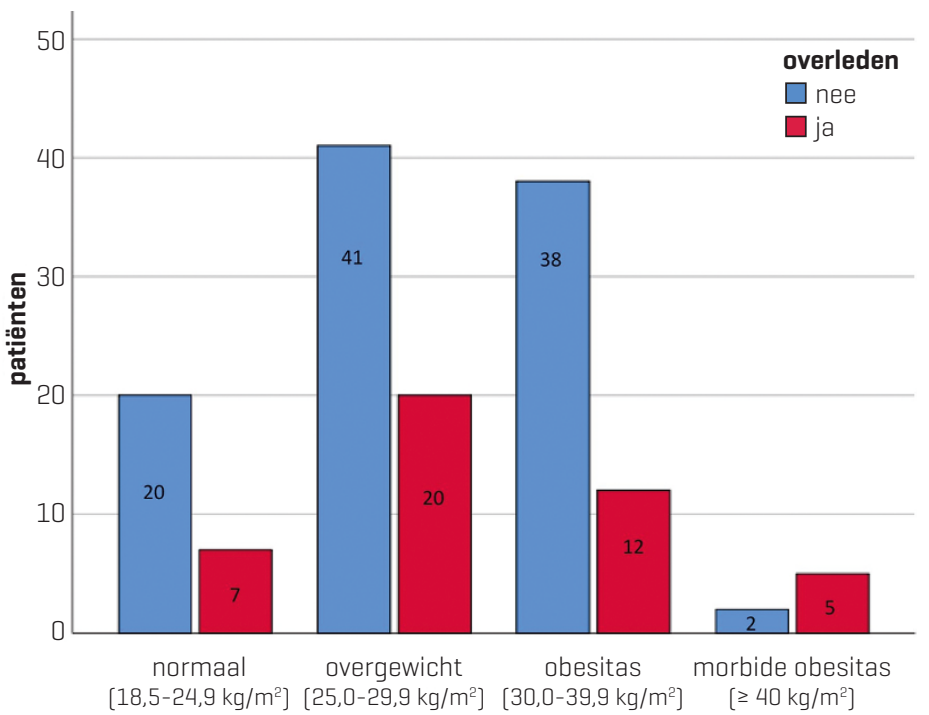

95\% (IQR 93-97) en de gemiddelde systolische bloeddruk 133 $\mathrm{mmHg}(\mathrm{SD} 21,5)$ [tabel 2].

\section{Overlijden}

Hogere leeftijd en diabetes mellitus bleken significant geassocieerd met overlijden [online tabel 1]. De mediane leeftijd van patiënten die overleden was 78 jaar (IQR 74,8-82,0), die van patiënten die niet overleden 68 jaar (IQR 55,5-74,0; $\mathrm{p}<0,001)$. Van de overleden patiënten had $31,4 \%$ diabetes mellitus, van de niet-overleden patiënten $16,2 \%(\mathrm{p}=0,008)$. Hart- en vaatziekten $(p=0,037)$, hypertensie $(p=0,037)$ en maligniteit $(\mathrm{p}=0,05)$ waren eveneens significant geassocieerd met overlijden.

Bij de laboratoriumuitslagen valt op dat overlijden significant geassocieerd was met een hoger CRP (103 versus $89 \mathrm{mg} / \mathrm{l}$; $\mathrm{p}=$ 0,008), hoger $\mathrm{LDH}$ (406 versus $327 \mathrm{U} / \mathrm{l} ; \mathrm{p}=<0,001$ ), hoger ASAT (51 versus $38 \mathrm{U} / \mathrm{l} ; \mathrm{p}=0,003)$, hoger lactaat $(1,6$ versus $1,3 \mathrm{mmol} / \mathrm{l} ; \mathrm{p}=<0,001)$ en lager lymfocytenpercentage $(10$ versus $16 \% ; \mathrm{p}=<0,001)$ [online tabel 1 ].

\section{Ic-opname}

Hogere leeftijd en diabetes mellitus bleken ook significant geassocieerd te zijn met ic-opname [online tabel 3]. De mediane leeftijd van patiënten die op de ic werden opgenomen, was 70 jaar (IQR 63,2-76,0) die van de niet-opgenomen patiënten was 64 jaar (IQR 53,0-73,0; p = 0,024). Van de patiënten die werden opgenomen had 35,0\% diabetes mellitus, bij de niet opgenomen patiënten was dat $12,7 \%(\mathrm{p}=0,002)$.

Bij de laboratoriumuitslagen valt op dat ic-opname significant geassocieerd was met een hoger CRP (154 versus $79 \mathrm{mg} / \mathrm{l}$; $\mathrm{p}<$ 0,001), hoger LDH (390 versus $303 \mathrm{U} / \mathrm{l} ; \mathrm{p}<0,001$ ), lager lymfocytenpercentage ( 11 versus $17 \%$; $<<0,001$ ) en lager bicarbonaat 
Voorspellers voor overlijden en ic-opname in de multivariabele analyse

\begin{tabular}{|c|c|c|c|c|}
\hline \multirow[t]{2}{*}{ Variabelen } & \multicolumn{2}{|l|}{ Overlijden [ $n=70]$} & \multicolumn{2}{|l|}{ ic-opname $[n=40]$} \\
\hline & OR [95\%-BI] & $\mathbf{p}$ & OR [95\%-BI] & $\mathbf{p}$ \\
\hline Leeftijd & $1,10[1,06$ tot 1,15$]$ & $<0,001$ & $1,02[0,99$ tot 1,05$]$ & 0,26 \\
\hline Diabetes mellitus & $2,17[1,03$ tot 4,57$]$ & 0,04 & $3,26[1,37$ tot 7,77$]$ & 0,01 \\
\hline Cardiovasculaire ziekte & $0,75[0,39$ tot 1,45$]$ & 0,39 & - & - \\
\hline Hypertensie & $0,95[0,49$ tot 1,84$]$ & 0,88 & - & - \\
\hline Maligniteit & $1,79[0,85$ tot 3,8$]$ & 0,13 & - & - \\
\hline
\end{tabular}

Significante waarden $[p<0,05]$ zijn vet weergegeven.

(22 versus $23 \mathrm{mmol} / \mathrm{l} ; \mathrm{p}=0,019$ ). Ook bilaterale infiltratieve afwijkingen op de X-thorax waren significant geassocieerd met ic-opname $(\mathrm{p}=0,026)$. Van de patiënten die werden opgenomen op de IC had $82,5 \%$ bilaterale infiltratieve afwijkingen, versus $60,5 \%$ van de patiënten zonder ic-opname [tabel 3].

\section{Voorspellende variabelen}

Om te bepalen welke patiëntkenmerken een slechter ziektebeloop voorspellen, voerden we een multivariabele logistische regressieanalyse uit van een aantal variabelen die in de univariabele analyse significant bleken (leeftijd, diabetes mellitus, cardiovasculaire ziekte, hypertensie en maligniteit).

Leeftijd $(\mathrm{p}<0,001)$ en diabetes mellitus $(\mathrm{p}=0,04)$ bleken onafhankelijke voorspellers voor het overlijden van COVID-19-patiënten. De odds ratio (OR) voor leeftijd was 1,10 . Dat betekent dat de odds om te overlijden voor een patiënt die 1 jaar ouder is 1,10 keer zo hoog zijn als voor een patiënt die 1 jaar jonger is. Voor een patiënt met diabetes mellitus zijn de odds op overlijden, gecorrigeerd voor leeftijd, cardiovasculaire ziekten, hypertensie en maligniteit, 2,17 keer zo hoog als voor een patiënt zonder deze ziekte.

Diabetes mellitus bleek tevens een onafhankelijke voorspeller voor ic-opname (OR 3,26; $p<0,001$, gecorrigeerd voor leeftijd) [tabel 4].

We hebben ook gekeken naar de rol van overgewicht [figuur]. In onze populatie had $81,4 \%$ van de patiënten een BMI $>24,9$ $\mathrm{kg} / \mathrm{m}^{2}$. Om twee redenen hebben we besloten BMI echter niet mee te nemen in de multivariabele analyse. Ten eerste bleek een hogere BMI in onze univariabele analyse niet significant geassocieerd met een slechter ziektebeloop en ten tweede was het aantal ontbrekende waarden te groot $(n=98)$ voor een nauwkeurige multivariabele analyse. Ook als we BMI zouden hebben meegenomen in de multivariabele analyse, zouden leeftijd ( $p=0,001)$ en diabetes mellitus $(p=0,037)$ alsnog de enige onafhankelijke voorspellers van overlijden blijven (data niet weergegeven).

Onze gegevens wijzen er dus niet op dat een hogere BMI geassocieerd is met een grotere kans op overlijden of ic-opname voor COVID-19-patiënten. Een direct verband tussen diabetes mellitus en obesitas hebben we in dit onderzoek evenmin gevonden ( $\mathrm{p}=0,396$; data niet weergegeven).

\section{BESCHOUWING}

COVID-19 is op de SEH een ernstig ziektebeeld met een breed scala aan symptomen. ${ }^{2,3}$ Dit onderzoek is het eerste dat zich richt op de risicofactoren voor een slechter beloop van COVID-19 in de Nederlandse populatie. De uitkomst is dat diabetes mellitus type 2 en hogere leeftijd geassocieerd zijn met een hogere kans op ic-opname en/of overlijden.

\section{Vergelijking met ander onderzoek}

We analyseerden de gegevens van 243 patiënten. Wat betreft geslacht, leeftijd en klinische presentatie was deze populatie vergelijkbaar met die in de omliggende Noord-Brabantse ziekenhuizen. Daar werd 15-19\% van de COVID-19-patiënten die de SEH bezochten uiteindelijk opgenomen op de ic en overleed $20-22 \%{ }^{2,3}$ In ons onderzoek werd $16,5 \%$ opgenomen op de ic (25,3\% van de patiënten met een ic+-beleid) en overleed $28,8 \%$. Een mogelijke verklaring hiervoor is de langere looptijd van ons onderzoek; in de omliggende ziekenhuizen was ten tijde van de onderzoeken nog circa $46 \%$ van de populatie opgenomen. ${ }^{2,3}$

Eerdere onderzoeken hebben aangetoond dat SARS-CoV-2 vooral oudere patiënten treft en dat hogere leeftijd een predisponerende factor is voor een slechtere uitkomst. . $^{2-4,6-8}$ Dit blijkt ook uit onze resultaten. Over diabetes mellitus is de literatuur echter verdeeld. Deze ziekte lijkt wel geassocieerd met een slechter beloop (acute respiratory distress syndrome) of overlijden, maar vaak niet als onafhankelijke factor. ${ }^{4,9,10}$ Dit komt niet overeen met onze resultaten. De prevalentie van diabetes mellitus $(20,6 \%)$ in onze populatie is nagenoeg gelijk aan die in de eerdere onderzoeken. ${ }^{2,3,6,8}$ Daarnaast laat ons onderzoek zien dat een strenger beleid inzake ic-opname bij patiënten met comorbiditeit (zoals diabetes mellitus) het slechtere beloop niet kan verklaren, aangezien diabetes mellitus ook bij patiënten met een ic+-beleid geassocieerd was met een slechter beloop.

Meerdere internationale onderzoeken laten zien dat hypertensie een predisponerende factor is voor een ernstiger ziektebeloop van COVID-19., Uit onze resultaten komt dit echter niet naar voren. Hypertensie kwam in onze onderzoekspopulatie wel relatief vaak voor bij patiënten met een slechter ziektebeloop, maar was geen onafhankelijke predisponerende factor. 
En rol kan spelen dat wij hypertensie definieerden als 'hypertensie in de voorgeschiedenis' of 'gebruikt antihypertensiva', maar niet registreerden of de hypertensie goed gereguleerd was en welke antihypertensiva de patiënt gebruikte. Het is goed mogelijk dat het cardiovasculair risicomanagement in Nederland en etnische verschillen tussen de onderzoekspopulaties verklaren waarom hypertensie in ons onderzoek geen significante risicofactor was.

\section{Implicaties voor de huisartsenpraktijk}

Leeftijd en diabetes mellitus type 2 blijken significante voorspellers voor ic-opname en overlijden van COVID-19-patiënten. Als zij COVID-19 vermoeden, kunnen huisartsen bij patiënten uit de genoemde risicogroepen advance care planning toepassen. Het is belangrijk tijdig met de patiënt te bespreken wat diens wensen zijn ten aanzien van ziekenhuisopname en (vaak langdurige) opname op de ic. Daarbij moet men er rekening mee houden dat de kans op overlijden relatief groot is en dat de therapeutische opties op de reguliere verpleegafdelingen beperkt zijn tot zuurstof en antibiotische ondersteuning.

\section{Sterke en zwakke punten}

Sterke punten van dit onderzoek zijn dat de onderzoekspopulatie relatief groot was $(n=243)$ en dat dit het eerste $\mathrm{Ne}$ derlandse onderzoek is waarin naast beschrijvende statistiek ook gezocht is naar risicofactoren voor een slechter beloop van COVID-19. Een ander sterk punt is dat we naast een univariabele analyse ook een multivariabele analyse hebben uitgevoerd waarin alle significante variabelen zijn meegenomen.

Het onderzoek heeft ook enkele beperkingen. Ten eerste zijn de data verzameld door 5 onderzoekers, wat de interobserverreproduceerbaarheid beïnvloedt. We hebben geprobeerd die te vergroten door alle onderzoekers dezelfde, uniforme uitleg te geven over hoe de data verzameld en geïnterpreteerd moesten worden. Ten tweede hebben we getracht te corrigeren voor confounders middels een multivariabele logistische regressieanalyse, maar konden we gezien de grootte van ons cohort niet alle comorbiditeiten meenemen. De kans op confounders blijft hierdoor aanwezig.
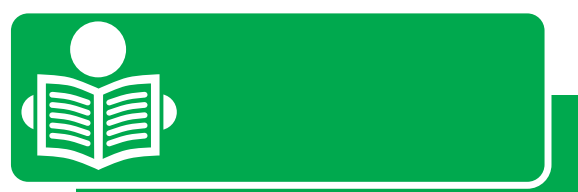

Lees meer over COVID-19 in ons COVID-19-dossier op www.henw.org/dossiers/covid-19.

Benieuwd naar het verhaal achter dit artikel? Beluister de podcast op www.huisartspodcast.nl/henw/

\section{CONCLUSIE}

Ons onderzoek heeft meer inzicht opgeleverd in het beloop van COVID-19-pneumonitis bij Nederlandse patiënten. Diabetes mellitus type 2 en een hogere leeftijd zijn geassocieerd met een ernstiger beloop, gedefinieerd als ic-opname en/of overlijden. Ons advies zou zijn om, zodra er een vaccin voor COVID-19 beschikbaar is, de hoogrisicogroep, dus patienten $>65$ jaar met diabetes mellitus, als eerste voor vaccinatie in aanmerking te laten komen.

\section{LITERATUUR}

1. Actuele informatie over het nieuwe coronavirus (COVID-19). Bilthoven: RIVM, 2020, https://www.rivm.nl/coronaviruscovid-19/actueel, geraadpleegd 24 april 2020,

2. Buenen AG, Wever PC, Borst DP, Slieker KA. COVID-19 op de Spoedeisende Hulp in Bernhoven. Ned Tijdschr Geneeskd 2020;164:D5001.

3. Murk J-L, Van de Biggelaar R, Stohr J, Verweij J, Buiting A, Wittens S, et al. De eerste honderd opgenomen COVID-19patiënten in het Elisabeth-Tweesteden Ziekenhuis. Ned Tijdschr Geneeskd 2020;164:D5002.

4. Wu C, Chen X, Cai Y, Xia J, Zhou X, Xu S, et al. Risk factors associated with acute respiratory distress syndrome and death in patients with coronavirus disease 2019 pneumonia in Wuhan, China. JAMA Intern Med 2020;180:1-11.

5. Yang J, Zheng Y, Gou X, Pu K, Chen Z, Guo Q, et al. Prevalence of comorbidities in the novel Wuhan coronavirus (COVID-19) infection: a systematic review and meta-analysis. Int J Infect Dis 2020;94:91-5.

6. Richardson S, Hirsh JS, Narasimhan M, Crawford JM, McGinn T, Davidson KW, et al. Presenting characteristics, comorbidities, and outcomes among 5700 patients hospitalized with COVID19 in the New York City area. JAMA 2020;323:2052-9.

7. Zangrillo A, Beretta L, Scandroglio AM, Monti G, Fominskiy E, Colombo S, et al. Characteristics, treatment, outcomes and cause of death of invasively ventilated patients with COVID-19 ARDS in Milan, Italy. Crit Care Resusc 2020 [online ahead of print].

8. Chen R, Liang W, Jiang M, Guan W, Zhan C, Wang T, et al. Risk factors of fatal outcome in hospitalized subjects with coronavirus disease 2019 from a nationwide analysis in China. Chest 2020;158:97-105.

9. Zhou F, Yu T, Du R, Fan G, Liu Y, Liu Z, et al. Clinical course and risk factors for mortality of adult inpatients with COVID-19 in Wuhan, China: a retrosprective cohort study. Lancet 2020;395:1054-62.

10. Huang I, Lim MA, Pranata R. Diabetes mellitus is associated with increased mortality and severity of disease in COVID-19 pneumonia - A systematic review, meta-analysis, and meta-regression. Diabetes Metab Syndr 2020;14:395-403.

Van den Oever W, Raaijmakers VT, Theunissen AM, Wijnen-van Houts MH, Frenken JG. Risicofactoren voor een ernstig beloop van COVID-19. Huisarts Wet 2020;63[10]:12-6. D0I:10.1007/s12445-020-0859-3. Elkerliek Ziekenhuis, afdeling Spoedeisende Hulp, Helmond: W. van den Oever, anios Spoedeisende Hulp en arts-klinisch onderzoeker, w.vandenoever@elkerliek.nl; V.T.P. Raaijmakers, anios Spoedeisende Hulp en anios Intensive Care; A.M.L. Theunissen, anios Spoedeisende Hulp, anios Intensive Care en arts-klinisch onderzoeker; M.H.H. Wijnen-van Houts, SEH-arts; J.G.M. Frenken, SEH-arts en medisch manager. Mogelijke belangenverstrengeling: niets aangegeven. 